\title{
Early graptolite research: Eduard Suess and the Bilimek collection
}

\author{
Barbara Hopfensperger, Jörg Maletz, Petra Lukeneder, \\ Petra Heinz \& Franz Otther
}

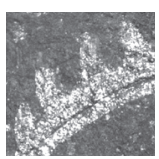

\begin{abstract}
Eduard Suess was one of the first scientists to describe graptolites from the Czech Republic. He erected one new genus and several new species. However, some of the material used for his descriptions has never been identified and the concept of the taxa was not verifiable. Some of the specimens are now recognized in the Bilimek collection (University of Natural Resources and Life Sciences, Vienna, Austria) and others are present in the Barrande collection of the National Museum (Prague, Czech Republic). The genus Petalolithus Suess, 1851 has subsequently been modified considerably and all of the species discussed by Suess are now referred to the genus Parapetalolithus. New species (with modern genus assignment) include Stomatograptus grandis, Expansograptus ferrugineus, Oktavites falx and Streptograptus barrandei. Petalolithus parallelocostatus is regarded as a synonym of Parapetalolithus palmeus and Graptolithus armatus is a synonym of Torquigraptus proteus. The taxa Graptolithus laevis and Graptolithus taenius cannot be referred to valid graptolite genera or species. - Key words: Silurian, graptolites, Suess, Bilimek, Czech Republic.
\end{abstract}

Hopfensperger, B., Maletz, J., Lukeneder, P., Heinz, P. \& Ottner, F. 2021. Early graptolite research: Eduard Suess and the Bilimek collection. Bulletin of Geosciences 96(3), 279-293 (4 figures, appendix). Czech Geological Survey, Prague. ISSN 1214-1119. Manuscript received March 11, 2020; accepted in revised form May 7, 2021; published online May 23, 2021; issued July 4, 2021.

\begin{abstract}
Barbara Hopfensperger, Department of Classical Archaeology, University of Vienna, Franz Klein-Gasse 1, 1190 Vienna, Austria \& Department of Palaeontology, University of Vienna, Althanstrasse 14, 1010 Vienna, Austria $\bullet$ Jörg Maletz, FU Berlin, Institute of Geological Sciences, Malteserstrasse 74-100, Haus B 105, 12249 Berlin, Germany; Yorge@zedat.fu-berlin.de • Petra Lukeneder, Geological-Palaeontological Department, Natural History Museum Vienna, Burgring 7, 1010 Vienna, Austria \& Department of Palaeontology, University of Vienna, Althanstrasse 14, Vienna, Austria • Petra Heinz, Department of Palaeontology, University of Vienna, Althanstrasse 14, Vienna, Austria • Franz Ottner, Institute of Applied Geology, University of Natural Resources and Life Sciences, Peter-Jordan-Strasse 82, 1190 Wien, Austria
\end{abstract}

Eduard Suess (20 August 1831-26 April 1914) is probably not best known for his graptolite research, but graptolites provided the start of his scientific career and thus, it is interesting and important to have an understanding of this palaeontological work and to be able to investigate the material on which he was working. Suess (Fig. 1A) wrote only a single paper on graptolites (Suess 1851a), but it includes the first descriptions of a number of graptolite taxa. These are still used today, even though the material on which the species were described remained largely unknown. Some of the originals of his illustrations were recently discovered in the collection of Dominik Bilimek (Fig. 1B) and are used as the basis for the understanding of the graptolite work of Suess. A short abstract of a presentation on the Graptolite Shales or Utica Shales from 19 April 1851 (Suess 1851b) may indicate that Suess intended more work on graptolites, but this did not materialize, most likely due to the unfavourable critique by Joachim Barrande (see Barrande 1852).
When Suess (1851a) described the 'Böhmische Graptolithen', he was one of the first scientists to work in this field, but his start was difficult and when he presented his research to Joachim Barrande prior to his publication in 1850 , Barrande immediately rushed to publish his own research on graptolites, for priority reasons, in a still fairly incomplete state as he even noted in his introduction ['dans cet état incomplet': Barrande 1850, p. 3]. On the other hand, E. Suess studied Barrande's graptolite collection made available to him by J. Barrande himself. Soon after receiving the publication of Suess in 1851, Barrande wrote devastating comments about the research of Suess (Barrande 1852, p. 155), describing the paper as a work without content ['inhaltslose Arbeit'] and regarded it as unacceptable, based on poor and incomplete material. He even questioned the scientific competence of Suess and as a result, Suess never again published on graptolites. Suess $(1916$, pp. 74, 75) later wrote about his encounter with Joachim Barrande and noted that he had to revise his 
thesis and did it 'in the most loyal way; Barrande opened his polemic; I did not answer' ['Ich tat es in loyalster Weise; Barrande eröffnete eine Polemik; ich antwortete nicht']. Showing a little humour, he further stated that his introduction into the scientific literature started under poor weather conditions ['So vollzog sich mein Eintritt in die wissenschaftliche Literatur - bei schlechtem Wetter.'].

Suess went on to become successful as a palaeontologist (Zapfe 1981), became one of the leading experts on the tectonic evolution of the Alps and developed ideas on the geological and palaeogeographical evolution of planet Earth (e.g. Suess 1883-1909: Das Antlitz der Erde). He is responsible for a number of concepts still used today: the Tethys Ocean, the supercontinent Gondwana and the theory of eustasy (Şengör 2014). Later, Suess (1854: Über die Brachiopoden der Kössener Schichten) used material from the Bilimek collection for his work on the Triassic brachiopods of the Kössen beds.

Suess (1851a) used graptolite material from several collections during his research, including material from the collection of Dominik Bilimek, the National Museum in Prague and he also had access to the collection of Joachim Barrande. Some specimens described by Suess were identified in the past, but the material from the Bilimek collection was not accessible until now and provides the main source of information presented herein.

The descriptions and interpretations of Suess (1851a) in some parts rely on an understanding that differs considerably from our modern understanding of graptolites. It reflects the approach at the very early state of the palaeontological investigation of graptolite faunas. This is clearly seen in the idea that the slender end of Retiolites is the 'oberes' Ende (the upper end: Suess 1851a, pp. 91, 92). This is in our modern understanding the proximal end of the colony, the end from which the colony started to grow. Despite these misunderstandings - and there are more in his discussions - the description of recognizable details is quite accurate and useful. A good example is his observation that the main axis (Hauptachse) in Retiolites may be forming a zigzag line (Zickzack-Linie). This is a first and correct description of the reverse side in Retiolites, in which zigzag lists form the centre of the lateral thecal wall, while on the obverse side the straight nema is incorporated in the lateral thecal wall (see Lenz et al. 2018, fig. 9.2). In completely preserved specimens, these features may be covered by the ancora sleeve meshes as is seen in the lower part of the recognized possible original specimen (Fig. 3C) of his illustration (Fig. 2N). Suess (1851a, pl. 7, fig. 1a) showed a longer specimen, in which at least distally, the nema is indicated as a straight line, similar to the situation in his possibly illustrated specimen (Fig. 3C). Thus, his observations were quite precise and can be supported by the now identified specimens.

\section{The Bilimek collection}

The Cistercian Dominik Bilimek (23 February 1813-03 August 1887) (Fig. 1B) was very interested in natural sciences and amassed an enormously important scientific collection and maintained contact with numerous scientists during his life (see Roth 1965, 2016a, b; RiedlDorn 2001). When the Archduke of Austria, Ferdinand Maximillian Joseph (06 July 1832-19 June 1867) accepted the crown of Mexico, Bilimek followed him and moved to Mexico, where he became custodian of the Botanical and Entomological Department of the Natural History Museum in Mexico (1865-1867). After Maximilian's execution in June 1867, Bilimek took his collections back to Austria and moved to Vienna (Roth 2016b). Large parts of Bilimek's collections are now scattered across the world (Feest 1986; Roth 2016a, b). A smaller part stayed at the monastery Heiligenkreuz (Lower Austria) and remained untouched for a long time at the so-called 'Steinarchiv' (Roth 2016b). In 2013, the collection was donated to the University of Natural Resources and Life Sciences, Vienna (BOKU - Universität für Bodenkultur, Wien) for further investigation (Huber \& Huber 2016). The collection contains more than 15,000 minerals, fossils and rock samples amongst which graptolites (collected in 1850 in the Beroun region, Czech Republic) were discovered. A few objects were marked with a red seal and/or the lettering 'Suess' (Fig. 1D, E). These seals were understood to indicate importance of these objects and subsequently some of Suess's illustrated specimens were recognized (Hopfensperger 2020), supported by the notes of Suess (1851a) in his publication that he used material from the Bilimek collection. All graptolites from the collection were recently photographed and determined according to modern taxonomy and some were recognized as originals from Suess (1851a). Further illustration originals were photographed at the Natural History Museum Prague, Czech Republic.

\section{The graptolites}

All illustrated material in Suess (1851a) is revised and information on the preservation is provided in Appendix. Şengör (2021) discussed the style and quality of the palaeontological illustrations of Suess and considered them to be excellent, based on detailed investigation. In the style of the time, Suess very carefully showed the important characters, but left out what he did not consider important (Fig. 2). Şengör (2021) called this style 'the art of leaving out', citing Hans Cloos as coining this term. He discussed the illustrations of Retiolites geinitzianus by Suess (1851a) and compared them with photos of shale material and even with a chemically isolated specimen 


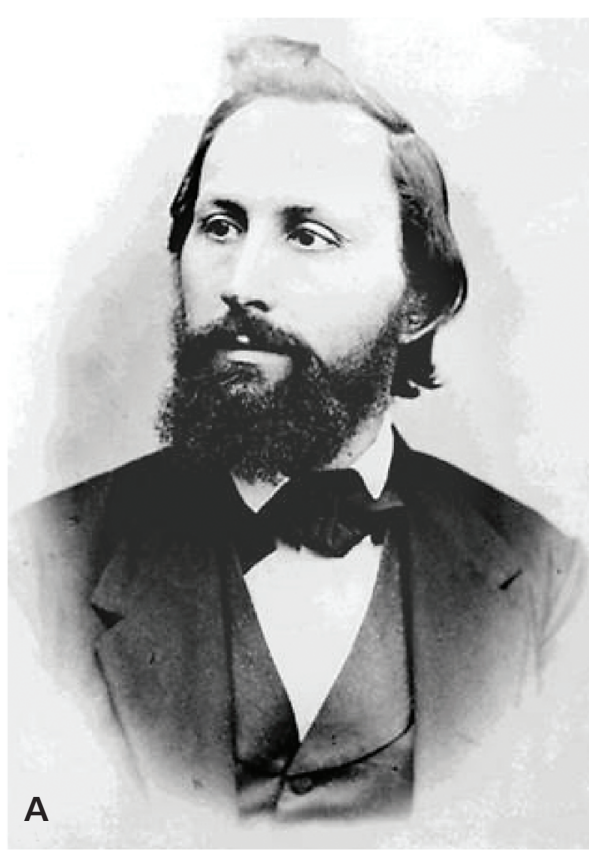

Eduard Suess (1831-1914)
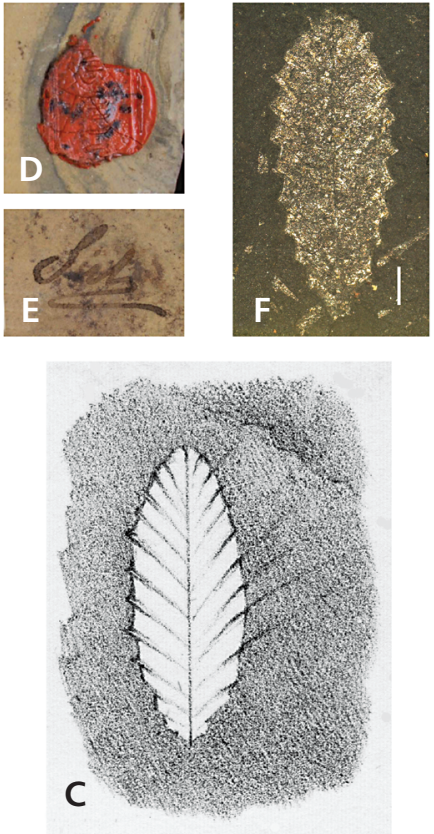

C

B

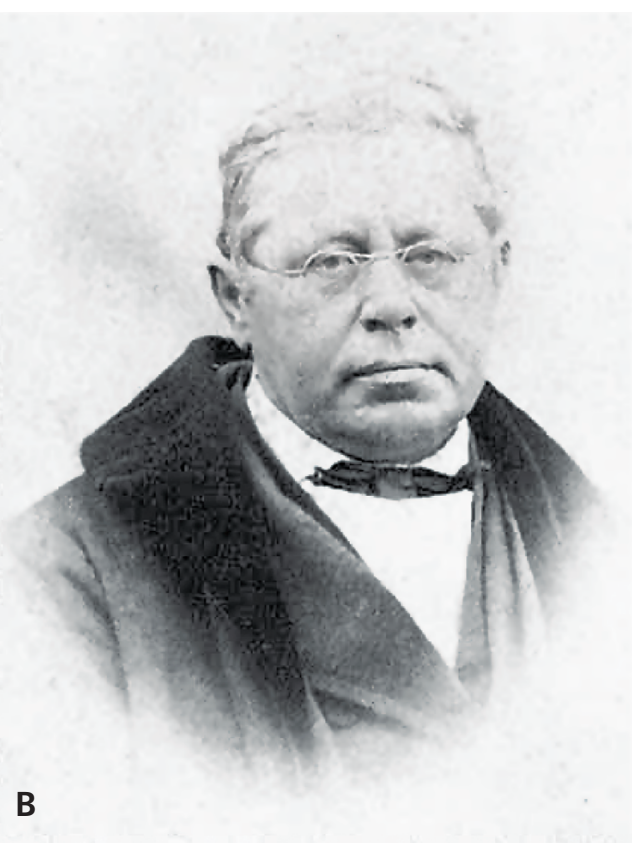

Dominik Bilimek (1813-1887)

Figure 1. A - Eduard Suess. • B - Dominik Bilimek (Photo: Museum of Natural History Vienna). $・$ C - original illustration of Suess (1851a, pl. 8 , fig. 4: Petalolithus ovatus). • D, E - red seal and signature 'Suess' on back of slab F 460 (Suess 1851a, pl. 8, fig. 2: Petalolithus parallelo-costatus). F - F 453a, photo of identified specimen of Parapetalolithus palmeus (Barrande, 1850) from the Bilimek collection (specimen originally identified as Petalolithus ovatus). Scale bar in $\mathrm{F}$ is $1 \mathrm{~mm}$.

to demonstrate the quality of Suess's drawings and interpretations. The understanding of Şengör (2021) can be supported by the comparison of the now recognized specimen of Retiolites geinitzianus in the Bilimek collection studied by Suess (see discussion above).

The example of Parapetalolithus palmeus (Fig. 1C: Petalolithus ovatus in Suess 1851a) can here be used to shows the skills of Suess. The specimen (Fig. 1F) is easily recognized from the original illustration (Fig. 1C). Suess's remark 'Man sieht nämlich die Nebenäste noch weit über den Umriss, ihre Richtung beibehaltend, sich verlängern (Fig. 4)' is illustrated by the lines to the right of the specimen continuing the interthecal septa. These lines are vaguely visible in the specimen under certain light directions (Fig. 1F), but may represent some tectonic distortion and not original features of the graptolite. A number of taxa are here illustrated by their original illustrations (Fig. 2) to demonstrate the quality of Suess's illustrations. The published plates are based on the original drawings of Suess and provide a good understanding of the intentions of the author. Discrepancies to the accepted modern understanding of the species described originally by Suess (1851a) are discussed in the text.

New taxa erected by Suess (1851a) are discussed in more detail. Only a few genus names were available for Suess (1851a, p. 89) to describe graptolites and a higher level taxonomy did not exist. Suess (1851a) differentiated three genera: Retiolites, Petalolithus and Graptolithus. In Graptolithus he recognized three types: (1) twodimensionally coiled, (2) three-dimensionally coiled and (3) the subgenus Rastrites with its isolated, slender metathecae. The first two groups include taxa that are now included in a number of separate genera, while the third, Rastrites, can easily be recognized also in the modern concept. The classification of the graptolites follows Maletz (2014, 2017).

\section{Systematic palaeontology}

Class Pterobranchia Lankester, 1877

Subclass Graptolithina Bronn, 1849

Order Graptoloidea Lapworth

in Hopkinson \& Lapworth, 1875

Suborder Dichograptina Lapworth, 1873

\section{Genus Expansograptus Bouček \& Přibyl, 1952}

\section{Expansograptus ferrugineus (Suess, 1851a)}

Figure 2C, F

Remarks. - Suess (1851a) noted that the illustrated material is preserved in the National Museum in Prague. Bouček (1973, fig. 13e) identified NM L7555 as the 
original specimen of Suess (1851a) and re-illustrated a small distal part of the specimen. He also provided a detailed description including the proximal end of the species from additional material. The species has a slender proximal end with a slender, vertically positioned sicula and shows considerable distal widening of the two stipes with their low inclined thecae.

The material originated from the Expansograptus ferrugineus Horizon of the neighbourhood of Hořovice, Fe-oolite mines, at the base of the Šárka Formation (Bouček 1973, p. 46). The specimen thus originates from the lower, but not lowest Darriwilian. Perner (1895) described the same taxon as Didymograptus lonchotheca.

Order Axonophora Frech, 1897

Infraorder Neograptina Štorch et al., 2011

Superfamily Retiolitoidea Lapworth, 1873

Family Retiolitidae Lapworth, 1873

Subfamily Petalolithinae Bulman, 1955

\section{Genus Petalolithus Suess, 1851}

Diagnosis. - Robust petalolithine with pattern I astogeny, possessing rectangular thecae with either straight or concave ventral sides; cross section of tubarium rectangular to oval; ancora present, sometimes also partial ancora sleeve with lists; partial median septum on obverse side (Lenz et al. 2018, p. 5).

Remarks. - Suess (1851a, p. 90) indicated the identity with the genus Diprion of Barrande (1850), a homonym of the hymenopteran genus Diprion Schrank, 1802. Suess (1851a) included several species in the genus Petalolithus, but these are now referred to the genus Parapetalolithus Koren' \& Rickards, 1996 after the subsequent designation of Prionotus folium Hisinger, 1837 as the type species of the genus by Lapworth (1873). Lapworth (1873) changed the genus name to Petalograptus and listed as the only example Petalograptus folium Hisinger, 1837. Loydell (1992, p. 36) discussed the status of the genus name and observed that the name Petalolithus has priority. The original name Petalolithus Suess, 1851 is now generally accepted (see Lenz et al. 2018).

Suess (1851a, p. 100) recognized the genus Petalolithus through its wide axis ('die Axe is breit, bandartig') and showed the shape of the nematularium (see Lenz et al. 2018) clearly in his illustrations. This characteristic nematularium is also present in the genus Parapetalolithus, to which the specimens described by Suess (1851a) are now referred. Interestingly, Suess (1851a, p. 101) treated some specimens with strong acid ('starker Säure') to see more details.

The formation of the ancora at the proximal end easily differentiates Petalolithus from Parapetalolithus Koren'
\& Rickards, 1996. An ancora is not present in any of the specimens described by Suess (1851a) and therefore all species originally included in Petalolithus by Suess (1851a) are now referred to Parapetalolithus instead.

\section{Genus Parapetalolithus Koren’ \& Rickards, 1996}

Diagnosis. - Petalolithine with pattern I proximal development type; first thecal pair straight, V-shaped; no median septum; nema free and central or embedded in obverse wall, often with extended nematularium; moderately inclined thecae with nearly straight ventral side and outwards inclined, straight thecal apertures (Lenz et al. 2018, p. 9).

Remarks. - The type species of the genus is Parapetalolithus dignus Koren' \& Rickards, 1996 from the Spirograptus guerichi Biozone (Telychian, lower Silurian) of the southern Urals of Russia.

\section{Parapetalolithus palmeus (Barrande, 1850)}

Figures 1C, F; 3E, G-I, K

Remarks. - Suess (1851a, pl. 8, fig. 1a-c) illustrated three specimens under the name Petalolithus palmeus, of which only one is here identified as Parapetalolithus palmeus (Barrande, 1850) (Fig. 3G) (Suess 1851a, pl. 8, fig. 1c). A second specimen (Suess 1851a, pl. 8, fig. 1a) can be identified as Parapetalolithus elongatus (Bouček \& Přibyl, 1941) (Fig. 3M). The third specimen (Suess 1851a, pl. 8, fig. 1b) has not been identified, but may belong to Parapetalolithus clavatus (Bouček \& Přibyl, 1941) with its typical distally narrowing tubarium.

Suess (1851a, pl. 8, fig. 2) described another specimen with a nice nematularium as his new species Petalolithus parallelo-costatus (Fig. 3H), a synonym of Parapetalolithus palmeus (Loydell 1992, p. 47). An additional specimen with a long and distally widening nematularium from the Bilimek collection is illustrated here (Fig. 3E), but was apparently not seen by Suess. Suess (1851a, p. 105) differentiated Petalolithus parallelocostatus from Petalolithus palmeus through a wider axis (nema/nematularium). The width of the nematularium is, however, variable based on preservational aspects and may not be used to differentiate these taxa.

Bouček \& Přibyl (1941) discussed the nomenclatural problems connected to the species and illustrated a number of specimens, including the specimen of Barrande (1850, pl. 3, fig. 3), which they identified as the lectotype of Parapetalolithus palmeus. Štorch (2000) provided a new drawing of the lectotype of the species.

Parapetalolithus elongatus (Bouček \& Přibyl, 1941) Figure 3J, M 


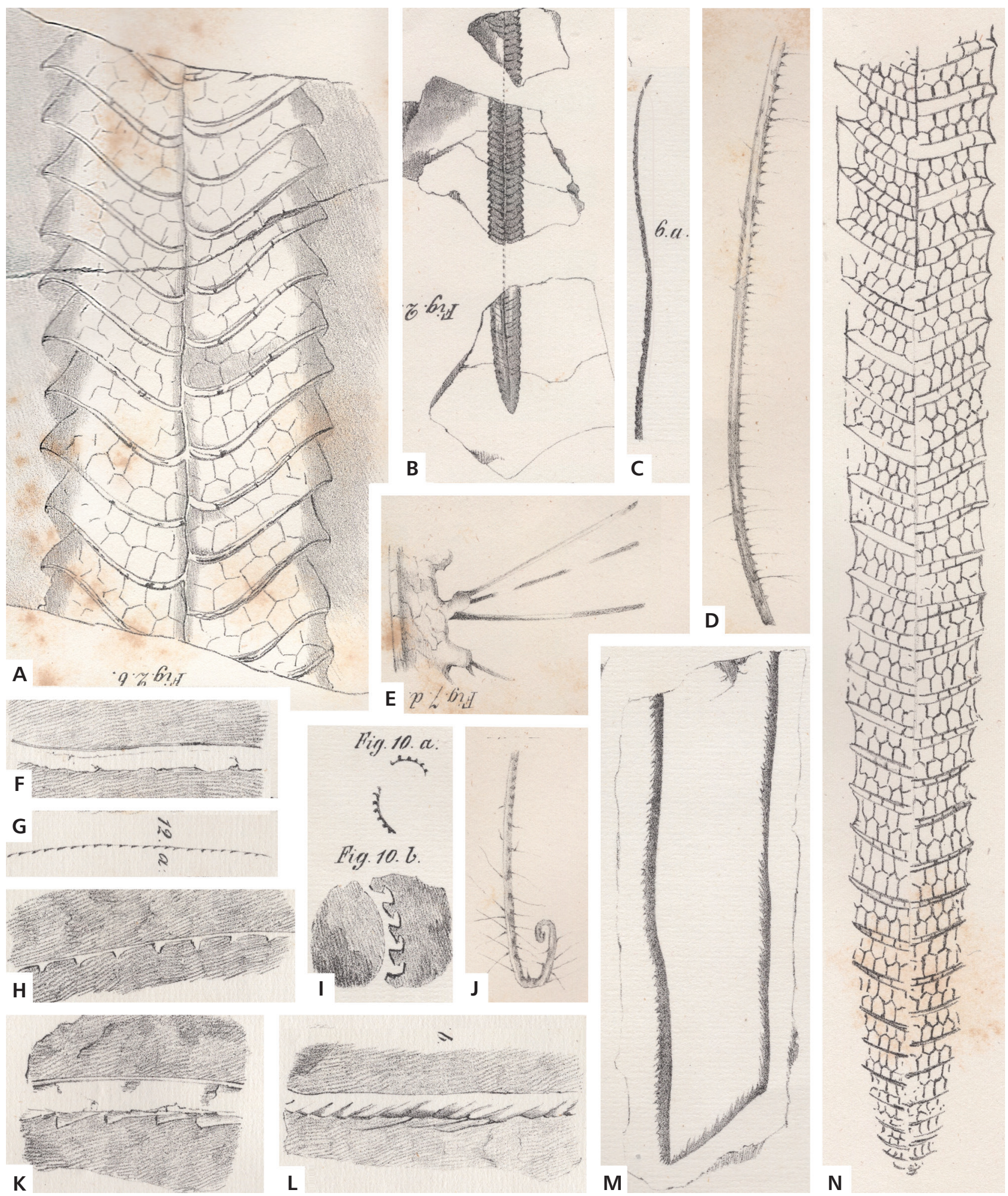

Figure 2. Examples of illustrations by Suess (1851a). A, B - Stomatograptus grandis, type specimen and magnification of central part (Suess 1851a, pl. 7, fig. 2a, b). • C, F - Graptolithus laevis (Suess 1851a, pl. 9, fig 6a, b). • D, E, J - Testograptus testis, F 445 (Suess 1851a, pl. 8, fig 7a, e). • G, H - Streptograptus barrandei (Suess 1851a, pl. 9, fig 12a, b). I - Oktavites falx (Suess 1851a, pl. 9, fig 10a, b). K - Graptolithus taenius (Suess 1851a, pl. 9, fig. 9). $・$ L, M - Expansograptus ferrugineus, holotype (Suess 1851a, pl. 9, fig 7a, b). $・ \mathrm{~N}-$ Retiolites geinitzianus, F 443 (Suess $1851 \mathrm{a}$, pl. 7, fig. 1b). All specimens in original illustration size, but orientation may be changed. 
Remarks. - Bouček \& Přibyl (1941) described the species from the Rastrites linnaei Biozone at Schelkowitz (Želkovice). The authors suggested that the specimen illustrated by Suess (1851a, pl. 8, fig. 1a) might belong to this taxon. This is supported here (Fig. 3M) and a second, more complete specimen from the Bilimek collection, but not illustrated previously, is also referred to Parapetalolithus elongatus (Fig. 3J).

\section{Parapetalolithus ovatus (Barrande, 1850) Figure 3L}

Remarks. - Suess (1851a, pl. 8, figs 3, 4) illustrated two specimens as Petalolithus ovatus, but they may be referred to Parapetalolithus palmeus now. Suess (1851a, p. 106) indicated that one of these specimens is in the Bilimek collection (Fig. 3I). The second one (Suess 1851 a, pl. 8, fig. 3) has not been identified. Figure $3 \mathrm{~K}$ shows another specimen from the Bilimek collection which might be this specimen, but the original illustration is too poor for verification. Bouček \& Přibyl (1941) described comparable specimens as Petalolithus cf. palmeus from the Rastrites linnaei Biozone. They might alternatively be regarded as younger (smaller) specimens of Parapetalolithus palmeus.

Two small (juvenile) specimens of Parapetalolithus ovatus were discovered in the Bilimek collection, but it is uncertain whether Suess investigated them. The bestpreserved specimen (Fig. 3L) is illustrated here for the first time. It shows the strongly curved thecae of this species, illustrated by Elles (1897) from larger specimens and differs considerably from the material identified as P. ovatus by Suess (1851a). Her material also comes from Želkovice, Czech Republic and originated from the Barrande collection as she indicated.

Barrande (1850, p. 63) described Parapetalolithus ovatus (Barrande, 1850) and illustrated a single specimen. Bouček \& Přibyl (1941) illustrated the now damaged holotype from the middle Rastrites linnaei Biozone (equivalent to the Spirograptus guerichi Biozone) of Želkovice near Beroun, Czech Republic. Štorch (2008) re-illustrated the specimen, but erroneously identified it as the lectotype. The specimen in the National Museum, Prague has the type number NM L27579. Loydell (1992) discussed the species.

Subfamily Retiolitinae Lapworth, 1873

\section{Genus Retiolites Barrande, 1850}

Diagnosis. - Tubarium initially slightly widening, then parallel sided, ovate in cross section; thecal framework fusellum very rarely preserved, showing thecal apertures inclined at $\sim 45^{\circ}$, lacking interthecal septa and accordingly thecal overlap; no geniculum; strongly developed thecal framework; ancora umbrella shallow, saucer-shaped with few polygonal meshes; ancora sleeve without fusellum and with dense reticulum; lateral apertural rods inclined at $45^{\circ}$ to $60^{\circ}$ to tubarium axis, thecal aperture defined by transverse rods, lateral apertural rods and thecal lips; without mid-ventral lists; thecal orifices more or less vertical; proximal thecae occasionally with reticular hoodlike structures; nema attached to transverse rods by connecting rods on obverse side; reverse side with zigzag lists; ancora sleeve without stomata; ancora sleeve lists with finely striated surface and seams facing outwards (Lenz et al. 2018, pp. 17, 18).

\section{Retiolites geinitzianus Barrande, 1850}

Figure $3 \mathrm{~A}-\mathrm{C}$

Remarks. - Barrande (1850) originally described the species as Gladiolites geinitzianus, but in a footnote changed the genus name to Retiolites as he realized the similarity to the plant genus Gladiolus. Suess (1851a) accepted the genus name Retiolites, and the name Gladiolites fell into disuse. His description of Retiolites geinitzianus Barrande, 1850 is very detailed but the interpretation of the recognized details does not fit the modern understanding of the genus. Suess (1851a, p. 94) noted that his observations were largely based on the investigation of material from the Bilimek collection. The specimens in the Bilimek collection are well preserved and show all of the details indicated by Suess (1851a) and specimen F 443 (Fig. 3C) has been identified possibly to represent one of the illustrated specimens. The comparison with the original illustration of Suess (1851a, pl. 7, fig. 1b) shows the same long tubarium with a partially exposed nema in the distal part, but covered more proximally in the colony (Fig. 2N). The ancora sleeve development is somewhat simplified by Suess (1851a), showing a less dense meshwork of lists in his drawings than visible in the original specimen. This simplification of the meshwork of the ancora sleeve is also visible in his illustration of Stomatograptus grandis (Fig. 2A). Bates \& Kirk (1997)

Figure 3. Retiolitidae. - A-C, F - Retiolites geinitzianus; A - F 681, long specimen, glued together from several fragments; B - F 2764, fragment; C-F 443 (specimen of Suess 1851a, pl. 7, figs 1a, b); F - F 448-2. • D - Pseudoretiolites sp., F 455. • E, G-I, K - Parapetalolithus palmeus; E - F 446, specimen with nice nematularium; G - F 440 (specimen of Suess 1851a, pl. 8, fig. 1c); H - F 460a (specimen of Suess 1851a, pl. 8, fig. 2; originally identified as holotype of Petalolithus parallelo-costatus Suess, 1851a); I- F 453a, small specimen (specimen of Suess 1851a, pl. 8, fig. 4); K - F 453b. - J, M - Parapetalolithus elongates; J - F 439d; M - F 439b (specimen of Suess 1851a, pl. 8, fig. 1a). • L - Parapetalolithus ovatus, F 434. Scale bars are $1 \mathrm{~mm}$ for all specimens. 
Barbara Hopfensperger et al. - Early graptolite research: Eduard Suess and the Bilimek collection
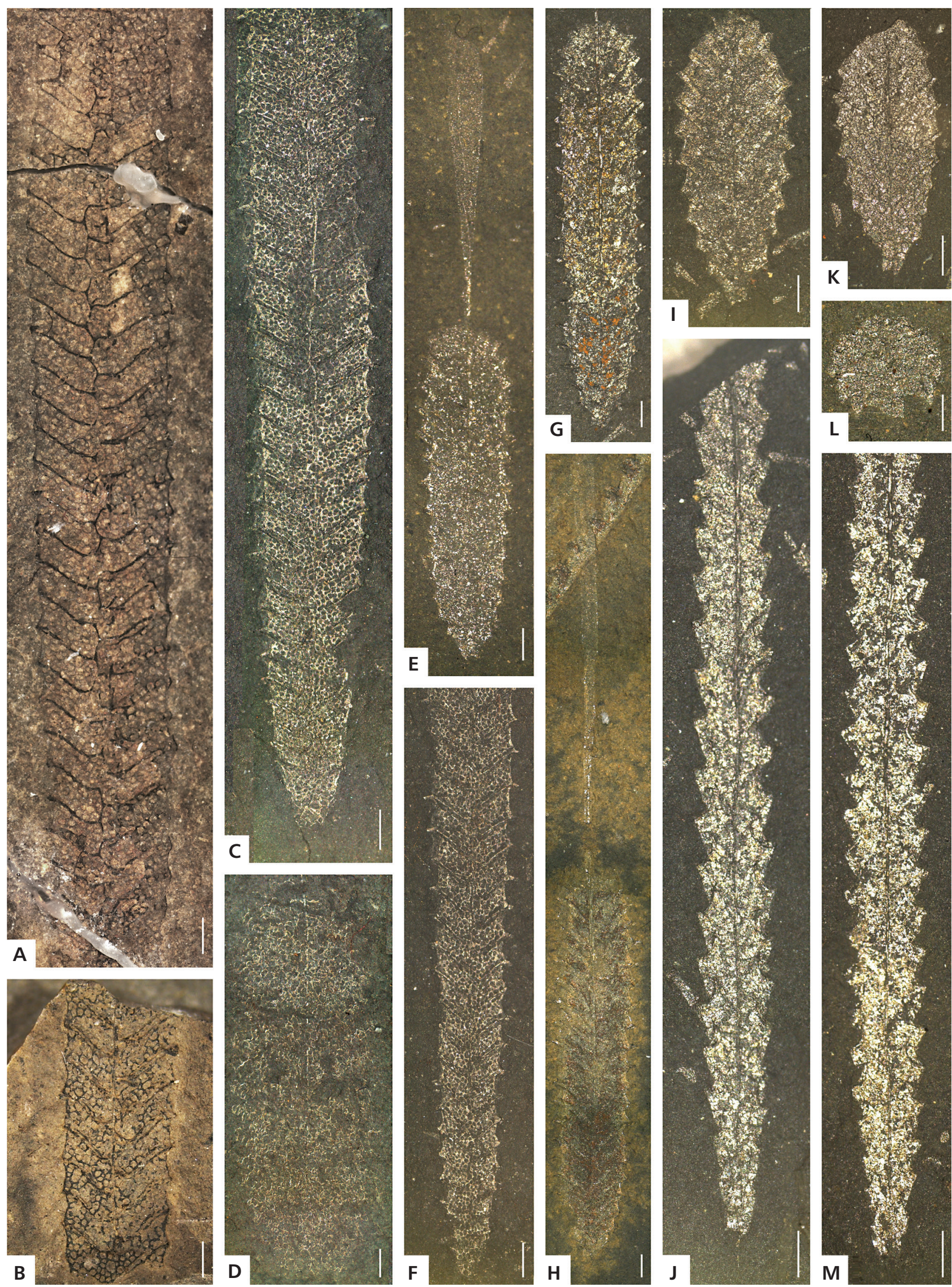
illustrated the complex meshwork of Stomatograptus grandis in SEM photos, showing a less regular development than indicated by Suess (1851a).

The zigzag lists on the reverse side of the tubarium in Retiolites geinitzianus are recognizable in one specimen (Fig. 3A) and at least parts of the nema are seen in others (Fig. 3B, C), suggesting the obverse side of the colony. The dimensions of the specimens in the Bilimek collection are quite variable and a lateral width of the colonies of less than $2 \mathrm{~mm}$ to more than $3.5 \mathrm{~mm}$ has been observed. It is unclear whether this is based on tectonic distortion or the involvement of more than one species (see Loydell et al. 1997).

The specimen of Retiolites geinitzianus with the number NM L27509 in the National Museum (Prague) has been recognized as illustrated in Suess (1851a, pl. 7, fig. 1), but it is probably not a specimen on which Suess based his illustrations. It is a long, fragmented specimen from Malá Chuchle, associated with specimens of the genus Monoclimacis. The label indicates its origin from the Barrande collection.

Loydell \& Štorch (1996) proposed NM L31612 as the neotype of Retiolites geinitzianus. The specimen is from the Llandovery Cyrtograptus murchisoni Biozone of Prague-Vyskočilka, Czech Republic, the type locality of Barrande (1850). The lectotype selected by Bouček \& Münch (1944, p. 37) is one of Barrande's specimens, but is too poor for a certain identification according to Loydell \& Štorch (1996).

A single specimen in the Bilimek collection was identified as Pseudoretiolites sp. during this investigation (Fig. 3D), showing a different style of the very delicate ancora sleeve lists. The specimen was not investigated by Suess, however.

\section{Genus Stomatograptus Tullberg, 1883}

Diagnosis. - Tubarium up to $16 \mathrm{~cm}$ long, slowly widening initially; prosicula present; sometimes fusellum of thecae preserved completely; sicula $0.7 \mathrm{~mm}$ long; mid-ventral lists absent; pleural lists strongly inclined, connecting thecal lip to succeeding lateral apertural list; nematularium present internally and externally in some specimens; thecae with straight, outward-inclined ventral side; ancora umbrella shallow to moderately bowl-shaped, with orderly hexagonal meshwork; ancora sleeve well developed, with polygonal to quadrilateral meshes; stomata present in all species; lists with finely striated surface; seams on outside of ancora sleeve lists (Lenz et al. 2018, p. 28).

\section{Stomatograptus grandis (Suess, 1851)}

(= Stomatograptus toernquisti Tullberg, 1883)

Figure 2A, B

Remarks. - Suess (1851a, p. 99) described this species as Retiolites grandis from the shales at Wiskočilka (Vyskočilka) near Prague and illustrated a single specimen. He differentiated the species through its size and the development of the thecal orifices. Barrande (1852, p. 145) regarded the species as a synonym of Retiolites geinitzianus. The original illustrations of this species (Fig. 2A, B) seem to show curved ventral apertural lips on the thecae and lack the characteristic stomata of Stomatograptus. Bouček \& Münch (1944, cf. fig. 13) referred similar material to Retiolites geinitzianus. They discussed Stomatograptus as a subgenus of Retiolites and stated that the characteristic stomata ['runde Fensterchen': Bouček \& Münch 1944, p. 572; German version] are not recognized in Bohemian specimens. The authors illustrated specimens of Stomatograptus grandis and Retiolites geinitzianus from Malá Chuchle-Vyskočilka.

Štorch et al. (2002, p. 102) selected NM L31630 from the Cyrtograptus lapworthi Biozone, Czech Republic as neotype of Stomatograptus grandis, as the whereabouts of the original specimen were not known. Holm (1890) described and illustrated Stomatograptus toernquisti Tullberg, 1883 from Gotland, based on chemically isolated material and specimens on rock surfaces. Holm clearly differentiated the fusellum of the thecae and the ancora sleeve lists in his material, as does Törnquist (1890) in Scanian material. Bouček \& Münch (1944) synonymized Stomatograptus toernquisti with Stomatograptus grandis. Bates \& Kirk (1997) described and illustrated additional material of the genus Stomatograptus from the Cape Phillips Formation (Canadian Arctic) in highly informative Scanning Electron Microscope (SEM) photos, showing the ancora sleeve development, but not the thecal fusellum.

Superfamily Monograptoidea Lapworth, 1873

Family Monograptidae Lapworth, 1873

Remarks. - Suess (1851a) described all taxa here referred to a number of monograptid genera under the genus name Graptolithus Linné. Notes are here provided for identified material and for taxa introduced by him as new. Suess (1851a) differentiated three groups, of which only one was named, the genus Rastrites Barrande, 1850.

\section{Genus Testograptus Přibyl, 1967}

Remarks. - Přibyl (1967) erected Testograptus as a subgenus of Monograptus and included several subspecies in the taxon. He included also Monograptus veles (Richter, 1871), now Cochlograptus veles (Richter, 1871) after (Obut 1987), with reservation in the genus. Urbanek \& Teller (1974) described Testograptus in great detail from chemically isolated material, as did Lenz \& Melchin (2008). 

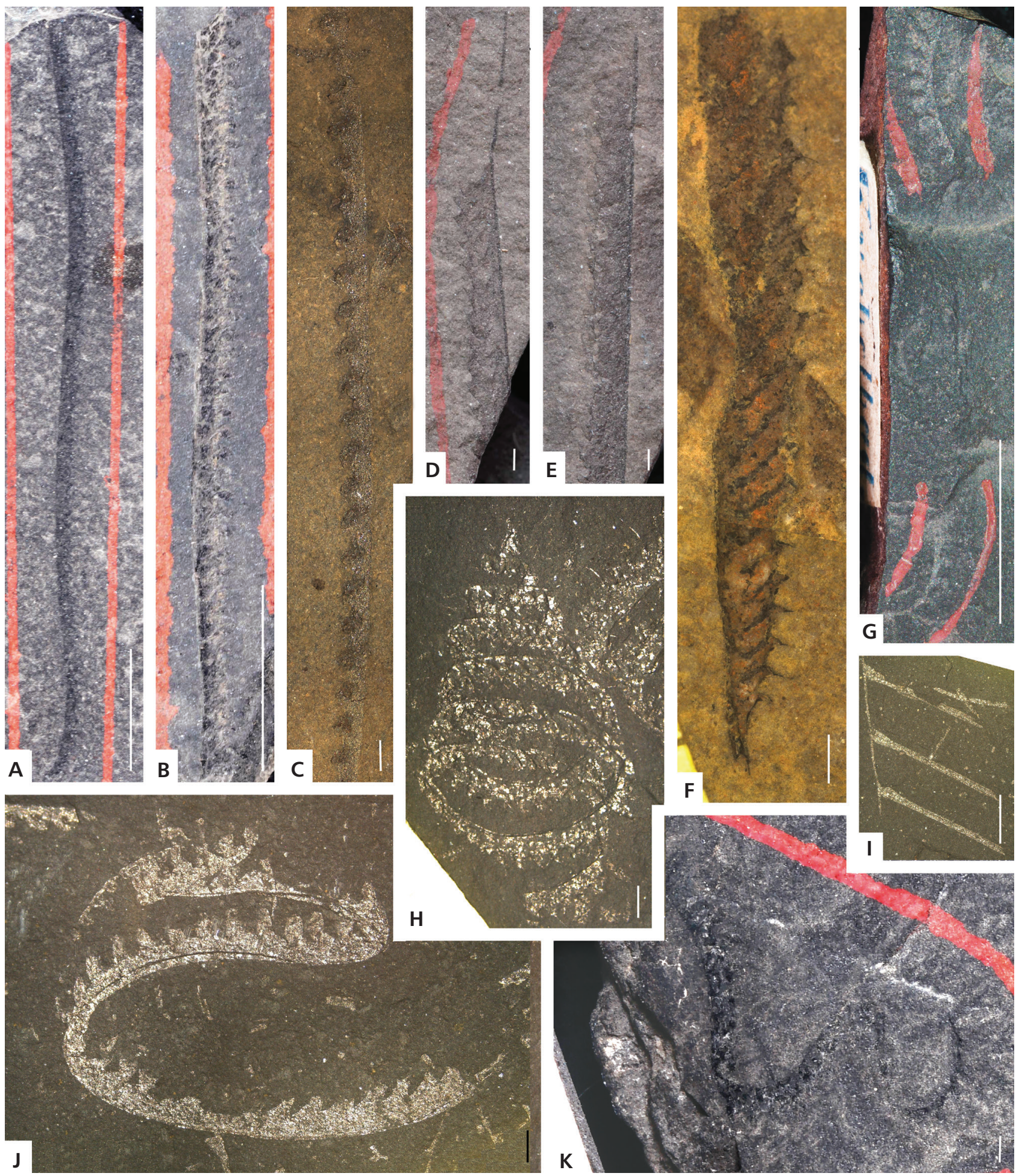

Figure 4. Monograptidae. • A - Graptolithus laevis, NM L31093, poorly preserved specimen (Suess 1851a, pl. 9, fig. 6). B - Monograptus indet., illustrated as Graptolithus convolutus (Suess 1851a, pl. 9, fig. 8), NML31092. • C - Streptograptus sp., F 460c, long fragment. • D, E - Pristiograptus dubius, NM L31094, ?syntypes, both on one slab (possibly Suess 1851a, pl. 9, fig. 5b). • F - Saetograptus chimaera, F 460b, proximal end. • G - Oktavites falx, NM L31091, two fragments on slab (possibly specimen of Suess 1851a, pl. 9, fig. 10). • H - Spirograptus turriculatus, F 451. • I - Rastrites linnaei, F 453b. • J - Torquigraptus proteus, F 439a. • K - Graptolithus armatus, holotype, NM L31095 (Suess 1851a, pl. 9, fig. 2); syn. of Torquigraptus proteus. Scale bar is $1 \mathrm{~mm}$ for all specimens, except A, B, G, where it is $10 \mathrm{~mm}$. 


\section{Testograptus testis (Barrande, 1850)}

Figure 2D, E, J

Remarks. - Suess (1851a) noted that the illustrated specimen is in the Bilimek collection, where it now has been identified on slab F 445. The specimen is poorly preserved, flattened or as a low relief imprint with little preservation of the organic fusellum. It is easily recognized as the illustrated specimen through the shape and the presence of the long spines. According to the collection label, the specimen comes from Litohlavy (formerly Litohlaw).

\section{Genus Pristiograptus Jaekel, 1889}

Remarks. - Jaekel (1889) erected the genus Pristiograptus based on material from glacial boulders of the GrünlichGraues Graptolithengestein of northern Germany. The neotype of Pristiograptus frequens (Jaekel, 1889) is from a glacial boulder of the Saetograptus chimaera Biozone found on the island of Hiddensee in the Baltic Sea (Jaeger 1991, fig. 26.9; Štorch et al. 2014). Urbanek et al. (2012) differentiated the species from Pristiograptus dubius (Suess, $1851)$ only through the presence of sicular annuli. Walker (1953) also discussed forms with and without sicular annuli ('Stillstandsgürtel') in Pristiograptus dubius.

\section{Pristiograptus dubius (Suess, 1851)}

Figure 4D, E

Remarks. - Přibyl (1943, p. 3; pl. 1, figs 4-6) called the two specimens illustrated by Suess (1851a) the holotype and illustrated a few specimens from the Wenlock Monograptus riccartonensis Biozone, Prague-Vyskočilka, Czech Republic for comparison. The two specimens of Suess (1851a) appear to originate from different localities and are too poor for identification, as they consist of distal stipe fragments. The specimens NM L27505 (loc. Malá Chuchle) and NM L31094 (loc. Praha-Dvorce) have been identified to represent the material illustrated by Suess (1851a, pl. 2, fig. 5a, b), but the identity is questionable. Two distal stipe fragments (Fig. 4D, E) from a single slab are illustrated here.

Urbanek (1997, p. 157) noted that the species has been described numerous times. It is well known from chemically isolated material from glacial boulders (Holm 1890, Cox 1934, Walker 1953, Kühne 1955, Urbanek 1958, and others). Numerous subspecies and closely related species have been described (see Urbanek et al. 2012), but the identity of the type material of Pristiograptus dubius (Suess, 1851) has never been verified. Štorch et al. (2014) discussed the problems of identifying this species based on the presence/absence of sicular annuli and indicated that possible topotype material of Pristiograptus dubius from the middle Sheinwoodian of the Prague Synform does not allow recognition of this character. A neotype should be chosen in the future among the specimens figured by Přibyl (1943).

\section{Genus Oktavites Levina, 1928}

\section{Oktavites falx (Suess, 1851)}

Figures 2J, 4G

Remarks. - The holotype is identified as NM L31091 from Malá Chuchle (Kuchelbad near Prague), Oktavites spiralis Biozone. The specimen was recognized in the Barrande collection, but Suess (1851a) did not mention the origin of his illustrated specimen. It is, thus, difficult to tell whether this specimen is the illustrated one, as it is found on a slab with two poor fragments, not showing thecal details (Fig. 4G). Přibyl (1945, p. 31) described and illustrated the species from a number of specimens. Loydell \& Nestor (2006) described chemically isolated material and showed the details of the thecal construction.

\section{Genus Streptograptus Yin, 1937}

\section{Streptograptus barrandei (Suess, 1851) Figure 2G, H}

Remarks. - Barrande (1852, p. 152) mentions two original specimens of Suess at his disposal, which may include the originally illustrated specimen. The specimen NM L31089 from the Barrande collection was identified as the illustrated one. It is difficult to compare to the illustrations of Suess (1851a) with the more robust specimen. The illustrations of Suess (Fig. 2H, I) show very slender prothecal parts and distally widening metathecae with knob-like apertural parts, suggesting a fragment from close to the proximal end of the species. Bouček \& Přibyl (1951, p. 7) indicated that the type was lost, but it was rediscovered by Loydell and Storch in the Barrande collection (Loydell 1993, p. 91). Loydell (1993, p. 90) described the species in some detail and determined the specimen in Suess (1851, pl. 9, fig. 12) as the holotype by monotypy. He indicated Želkovice, Bohemia as the type locality. Loydell (1993, p. 91) discussed the type specimen in some detail, but did not illustrate it. Loydell et al. (2017) illustrated the species from the Spirograptus guerichi Biozone of Bornholm, Denmark. A single not previously illustrated specimen from the Bilimek collection, possibly belonging to robust Streptograptus or even Stimulograptus species, is illustrated in Fig. 4C.

\section{Genus Graptolithus Linnaeus, 1768}

Remarks. - A number of taxa are here listed under the now 
abandoned genus Graptolithus (ICZN 1954) as they are not identifiable and referable to other genera. The names of these taxa should not be used unless their taxonomic identity can be established and the material would then be referred to the proper genus.

\section{Graptolithus armatus Suess, 1851}

Figure 4K

Remarks. - NM L31095 (Fig. 4K) was identified as the illustrated specimen, the holotype of Graptolithus armatus Suess, 1851a, but is now identified as Torquigraptus proteus (Barrande, 1850) by Loydell (1993, p. 119). The locality is Malá Chuchle (Kuchelbad near Prague). Suess (1851a) did not indicate where the specimen originated from, but the specimen from the Barrande collection is definitely identified as the illustrated specimen (Suess 1851a, pl. 9, fig. 2).

\section{Graptolithus laevis Hall, 1847}

Figures 2C, F; 4A

Remarks. - The specimen was identified as NM L31093, from Malá Chuchle (Kuchelbad near Prague). The material of Suess (1851a) certainly represents a monograptid fragment, but the poor preservation does not allow a better identification of the material. It is not related to Graptolithus laevis Hall, 1847 which was originally described from the Upper Ordovician Utica Shale of New York State. Ruedemann (1947) identified it as Mastigograptus laevis (Hall, 1847) and discussed the type material in detail.

\section{Graptolithus taenius Sowerby \& Salter, 1849 in Salter (1849)}

Figure 2L

The original drawing (Fig. 2L) shows a small fragment, probably of a slender Pristiograptus sp., but actually it is useless and the specimen is not identified. Sowerby \& Salter in Salter (1849) described this species as Graptolites tcenia, Sowerby and Salter, n. sp. from black slate of Wigtownshire. The authors described from the same locality a dicellograptid, identified as Graptolites sextans Hall and a long fragment as Graptolites tenuis Portlock, 1843. This material indicates a late Ordovician age. Strachan (1996, p. 7) indicated that the type of Graptolites teenia is an unidentifiable fragment of a uniserial stipe.

\section{Acknowledgements}

We thank Martin Valent, Petr Štorch, Jiří Kvaček (all Prague), Pater Meinrad Tomann (Heiligenkreuz; Austria) for supporting our work; P. Alkuin Schachenmayr (Austria) for access to the archive; A.M.C. Şengör (Istanbul, Turkey) provided the high resolution scans of the original plates of Suess (1851) used in Figs $1 \& 2$. Many thanks to the Austrian Academy of Sciences (ÖAW) for funding this project.

\section{References}

Barrande, J. 1850. Graptolites de Bohême-extrait du Systême Silurien de la Bohême. 74 pp. Privately printed, Prague.

Barrande, J. 1852. Bemerkungen über die Abhandlung des Hrn. Suess: „Ueber böhmische Graptolithen " (Naturwissenschaftliche Abhandlungen von Wilhelm Haidinger IV. Band, 4. Abth., S. 87). Jahrbuch der Kaiserlich-Königlichen Geologischen Reichsanstalt 3, 139-155.

BATES, D.E.B. \& KIRK, N.H. 1997. The ultrastructure, construction and functioning of the genera Stomatograptus and Retiolites, with an appendix on the incremental construction of the rhabdosome in Petalolithus, and its comparison with that of the thecal framework in Retiolites and Stomatograptus. Institute of Geography and Earth Sciences, University of Aberystwyth Publication 10, 1-168.

BoučEK, B. 1973. Lower Ordovician graptolites of Bohemia. 185 pp. Academia, Prague.

Bouček, B. \& Münch, A. 1944. Die Retioliten des mitteleuropäischen Llandovery und unteren Wenlock. Bulletin international de l'Academie tchéque des Sciences 44, 527-579.

BoučEK, B. \& Přıbyl, A. 1941. O rodu Petalolithus Suess z českého siluru (Über die Gattung Petalolithus Suess aus dem böhmischen Silur). Rozpravy České Akademie věd a umění, Třída II (Mitteilungen der Tschechischen Akademie der Wissenschaften 1941) 51(11), 1-22.

BoučEK, B. \& PřırYL, A. 1951. On some slender species of the genus Monograptus Geinitz, especially of the subgenera Mediograptus and Globosograptus. Bulletin international de l'Academie tchéque des Sciences 52, 1-32. Extrait du texte czeque publié dans la revue Rozpravy České Akademie věd a umění, Třída II 61(13), 1-31.

BoučEK, B. \& PřıbYL, A. 1952. Taxonomy and phylogeny of some Ordovician graptolites. Bulletin international de l'Academie tchéque des Sciences 52(20), 1-17.

BronN, H.G. 1835. Lethaea Geognostica. 768 pp. Schweizerbart, Stuttgart.

Bronn, H.G. 1849. Handbuch der Geschichte der Natur. Dritter Band, Zweite Abtheilung. II. Theil: Organisches Leben (Schluß). Index palaeontologicus oder Ueberblick der bis jetzt bekannten fossilen Organismen. 1106 pp. Schweizerbart, Stuttgart. DOI 10.5962/bhl.title.102095

Bulman, O.M.B. 1955. Graptolithina, 101 pp. In Moore, R.C. (ed.) Treatise on Invertebrate Paleontology, Part V. Geological Society of America \& University of Kansas Press, Lawrence.

Cox, I. 1934. On the structure of Monograptus dubius Suess. Annales and Magazine of Natural History 10(14), 421-435. DOI 10.1080/00222933408654915 
Elles, G.L. 1897. The subgenera Petalograptus and Cephalograptus. Quarterly Journal of the Geological Society of London 53, 186-212.

DOI 10.1144/GSL.JGS.1897.053.01-04.15

Elles, G.L. \& Wood, E.M.R. 1902. A monograph of British Graptolites. Part 2. Monograph of the Palaeontographical Society, London, 56(265), 55-102.

DOI 10.1080/02693445.1902.12035503

Feest, C.F. 1986. Maximilian, Miramar und Mexico, 67-69. In Rosero, L.R. (ed.) Massimiliano. Von Triest nach Mexico. Edizioni Linti, Trieste.

Frech, F. 1897. Lethaea geognostica oder Beschreibung und Abbildung für die Gebirgs-Formationen bezeichnendsten Versteinerungen. Herausgegeben von einer Vereinigung von Palaeontologen, 1. Teil - Lethaea Palaeozoica, 544-684 pp. E. Schweizerbart'sche Verlagshandlung, Stuttgart.

Hall, J. 1847. Paleontology of New York, Vol 1, Containing Descriptions of the Organic Remains of the Lower Division of the New York System (Equivalent of the Lower Silurian Rocks of Europe). 338 pp. Paleontological Society, Albany, State of New York.

Hisinger, W. 1837. Lethaea Suecica seu Petrificata Suecica, Supplementum 1. 124 pp. D.A. Norstedt et Filii, Stockholm.

Holm, G. 1890. Gotlands Graptoliter. Bihang till Kongliga Svenska vetenskaps Akademiens Handlingar 16(4), 1-34.

HopfensPerger, B. 2020. Revision of Silurian graptolites from the collection Bilimek, published by Eduard Suess (1851). 29 pp. B.Sc. thesis, University of Vienna, Austria.

Hopkinson, J. \& Lapworth, C. 1875. Descriptions of the graptolites of the Arenig and Llandeilo rocks of St. David's. Quarterly Journal of the Geological Society 31, 631-672.

DOI 10.1144/GSL.JGS.1875.031.01-04.49

Huber, S. \& Huber, P. 2016. Historische geowissenschaftliche Sammlungen in österreichischen Stiften. Berichte der Geologischen Bundesanstalt 118, 70-80.

ICZN (International Commission on Zoological Nomenclature). 1954. Opinion 197. Suppression, under the plenary powers, of the generic name "Graptolithus" Linnaeus, 1768 (class Graptolithina) and of the specific name "scalaris" Linnaeus, 1768 , as published in the combination "Graptolithus scalaris". Bulletin of Zoological Nomenclature 3(16), 209-216.

JAEGER, H. 1991. Neue Standard-Graptolithenzonenfolge nach der "Großen Krise" an der Wenlock/Ludlow-Grenze (Silur). Neues Jahrbuch für Geologie und Paläontologie, Abhandlungen 182(3), 303-354.

DOI 10.1127/njgpa/182/1991/303

JAEKEL, O. 1889. Ueber das Alter des sogen. Graptolithengesteins mit besonderer Berücksichtigung in demselben enthaltenen Graptolithen. Zeitschrift der Deutschen Geologischen Gesellschaft 41, 653-690.

Koren', T.N. \& Rickards, R.B. 1996. Taxonomy and evolution of Llandovery biserial graptoloids from the Southern Urals, western Kazakhstan. Special Papers in Palaeontology 54, $1-103$.

KÜHNE, W.G. 1955. Unterludlow-Graptolithen aus Berliner Geschieben. Neues Jahrbuch für Geologie und Paläontologie. Abhandlungen 100(3), 350-401.
LANKESTER, E.R. 1877. Notes on the embryology and classification of the animal kingdom; comprising a revision of speculations relative to the origin and significance of the germlayers. Quarterly Journal of Microscopical Science, New Series 17, 339-454. DOI 10.1242/jcs.s2-17.68.399

LAPwORTH, C. 1873. Notes on the British graptolites and their allies. 1. On an improved classification of the Rhabdophora, part 2. Geological Magazine 10, 555-560.

DOI $10.1017 / \mathrm{S} 0016756800469372$

Lenz, A.C. \& Melchin, M.J. 2008. Convergent evolution of two Silurian graptolites. Acta Palaeontologica Polonica 53, 449-460. DOI 10.4202/app.2008.0307

Lenz, A.C., Bates, D.E.B., KozŁowska, A. \& Maletz, J. 2018. Part V, second revision, Chapter 26: Family Retiolitidae: Introduction, morphology, and systematic descriptions. Treatise Online 114, 1-37.

LevinA, E.F. 1928. Graptolitit iz Aq-Tengi v Turkestanskom chrebte. Trudy Sredie-Aziatskogo Gosydarstvennogo Universiteta, Series 7a, Geologiya 5, 1-18.

LinNÆus, C. 1768. Systema naturce per regna tria naturce, secundum classes, ordines, genera, species, cum characteribus \& differentiis. Tomus III. 236 pp. Holmiæ. (Salvius). http://gdz. sub.uni-goettingen.de/dms/load/img/?PPN=PPN362053855 $\& I D D O C=215259$ DOI 10.5962/bhl.title. 156772

Loydell, D.K. 1992. Upper Aeronian and lower Telychian (LLandovery) graptolites from western mid-Wales. Part 1. Monograph of the Palaeontographical Society 146(589), $1-55$.

Loydell, D.K. 1993. Upper Aeronian and lower Telychian (LLandovery) graptolites from western mid-Wales. Part 2. Monograph of the Palaeontographical Society 14(592), 56-180.

Loydell, D.K. \& Nestor, V. 2006. Isolated graptolites from the Telychian (Upper Llandovery, Silurian) of Latvia and Estonia. Palaeontology 49(3), 585-619. DOI 10.1111/j.1475-4983.2006.00550.x

LoYdell, D.K. \& ŠTORCH, P. 1996. Gladiolites geinitzianus Barrande, 1850 (currently Retiolites geinitzianus; Graptolithina): proposed designation of a neotype. Bulletin of Zoological Nomenclature 53(4), 267-269. DOI 10.5962/bhl.part.14173

Loydell, D.K., ŠTorCh, P. \& Bates, D.E.B. 1997. Revision of the Silurian graptolite genus Retiolites. Palaeontology 40(3), 747-762.

Loydell, D.K., Walasek, N., Schovsbo, N.H. \& Nielsen, A.T. 2017. Graptolite biostratigraphy of the lower Silurian of the Sommerodde-1 core, Bornholm, Denmark. Bulletin of the Geological Society of Denmark 65, 135-160.

DOI 10.37570/bgsd-2017-65-09

Maletz, J. 2014. The classification of the Graptolithina Bronn, 1849. Bulletin of Geosciences 89(3), 477-540.

DOI 10.3140/bull.geosci.1465

Maletz, J. 2017. Part V, Second Revision, Chapter 13: The history of graptolite classification. Treatise Online 88, 1-11. DOI 10.17161/to.v0i0.6544

Овит, A.M. 1987. Cochlograptus - novyi rod siluriiskich graptolitov (Cochlograptus - a new genus of the Silurian 
graptolites). Trudy Instituta Geologii i Geofiziki 688, 140-144. [in Russian]

Perner, J. 1895. Études sur les graptolithes de Bohême. II ième Partie: Monographie des Graptolites de l'Étage D. 31 pp. Leipzig, Prague.

Perner, J. 1897. Études sur les graptolithes de Bohême. III ième Partie: Monographie des Graptolites de l'Étage E. 25 pp. Leipzig, Prague.

Portlock, J.E. 1843. Report on the Geology of the county of Londonderry, and of parts of Tyrone and Fermanagh. 784 pp. Dublin \& Londonderry.

Př́lbyl, A. 1943. Revise zástupců rodu Pristiograptus, ze skupiny $P$. dubius a $P$. vulgaris z českého a cizího siluru. Rozpravy České Akademie věd a uměni, Třída II 53(4), 1-48, 4 pls. (Revision aller Vertreter der Gattung Pristiograptus aus der Gruppe $P$. dubius und $P$. vulgaris aus dem böhmischen und ausländischen Silur. Bulletin international de l'Academie tchéque des Sciences 44, 33-81.).

PřIBYL, A. 1948. Bibliographic index of Bohemian Silurian graptolites. Knihovna Státního Geologického ústavu Republiky Československé 22, 1-97.

PřIBYL, A. 1967. Monograptus (Testograptus) subg. n. aus dem böhmischen und europäischen Silur. Věstník Ústředního ústavu geologického 42, 49-52.

Richter, R. 1871. Aus dem thüringische Schiefergebirge. Zeitschrift der Deutschen Geologischen Gesellschaft 23, 231-256.

Riedl-Dorn, C. 2001. Dominik Bilimek, 329-341. In SeIPEL, W. (ed.) Die Entdeckung der Welt, Die Welt der Entdeckungen. Österreichische Forscher, Sammler, Abenteurer. (Eine Ausstellung des Kunsthistorischen Museums Wien mit Museum für Völkerkunde und des Bundesministeriums für Bildung, Wissenschaft und Kultur in Zusammenarbeit mit dem Naturhistorischen Museum und dem Heeresgeschichtlichen Museum). Künstlerhaus, Wien \& Skira, Milano/Wien.

Rотн, H.J. 1965. Dominik Bilimek, Leben und Werk eines österreichischen Naturforschers. Sudhoffs Archiv für Geschichte der Medizin und der Naturwissenschaften 49(4), 338-354.

Rотн, H.J. 2016a. 'Der sterbende Kaiser' und sein Naturforscher. Dominik Bilimek, Zisterzienser im Dienste des Kaisers Maximilian von Mexico. 1. Folge. Magazin für Amerikanistik. Zeitschrift für amerikanische Geschichte 40(4), 17-21.

Rотн, H.J. 2016b. 'Der sterbende Kaiser' und sein Naturforscher. Dominik Bilimek, Zisterzienser im Dienste des Kaisers Maximilian von Mexico. 2. Folge. Magazin für Amerikanistik. Zeitschrift für amerikanische Geschichte 41(5), 39-43.

Ruedemann, R. 1947. Graptolites of North America. Geological Society of America, Memoir 19, 1-652.

DOI 10.1130/MEM19-p1

Salter, J.W. 1849. Note on the fossils from the limestones on the Stincher River, and from the slates of Loch Ryan. Quarterly Journal of the Geological Society of London 5, 13-17. DOI 10.1144/GSL.JGS.1849.005.01-02.08

Schrank, F. von Pavla. 1802. Fauna Boica. Durchdachte Geschichte der in Baiern einheimischen und zahmen Thiere.
Zweiter Band. 3412 pp. Johann Wilhelm Krüll, Ingolstadt. DOI 10.5962/bhl.title.44923

ŞENGör, A.M.C. 2014. Eduard Suess and global tectonics: an illustrated 'short guide'. Austrian Journal of Earth Sciences 107(1), 6-82.

ŞENGÖR, A.M.C. 2021. Eduard Suess on graptolites: His very first scientific paper and illustrations. In Clary, R.M., RosenberG, G.D. \& Evans, D.C. (eds) The Evolution of Paleontological Art. GSA Memoir 218. DOI 10.1130/2021.1218(09)

Štorch, P. 2000. Parapetalolithus palmeus (Barrande, 1850). In Zalasiewicz, J.A., Rushton, A.W.A., Hutt, J.E. \& Howe, M.P.A. (eds) Atlas of Graptolite Type Specimens, Folio 1.71.

Štorch, P. 2008. Parapetalolithus ovatus (Barrande, 1850). In Zalasiewicz, J.A., Rushton, A.W.A. (eds) Atlas of Graptolite Type Specimens, Folio 2.63.

Štorch, P., Manda, Š. \& Loydell, D.K. 2014. The early Ludfordian leintwardinensis graptolite event and the GorstianLudfordian boundary in Bohemia (Silurian, Czech Republic). Palaeontology 57, 1003-1043.

DOI 10.1111/pala.12099

Štorch, P., Serpagli, E. \& Barca, S. 2002. Silurian graptolites of the spiralis and lapworthi biozones (upper Telychian, Llandovery) in the Sulcis area, SW Sardinia. Bolletino della Società Paleontologica Italiana 41(2-3), 97-107.

Štorch, P., Mitchell, C.E., Finney, S.C. \& Melchin, M.J. 2011. Uppermost Ordovician (upper Katian-Hirnantian) graptolites of north-central Nevada, U.S.A. Bulletin of Geosciences 86(2), 301-386. DOI 10.3140/bull.geosci.1264

Strachan, I. 1996. A bibliographic index of British Graptolites (Graptoloidea). Part 1. Palaeontographical Society Monograph 150(600), 1-40.

Suess, E. 1851a. Über böhmische Graptolithen. Naturwissenschaftliche Abhandlungen von Wilhelm von Haidinger 4(4), 87-134.

Suess, E. 1851b. Skizze einer Arbeit über die Graptolithenoder Utica-Schiefer. Berichte über die Mittheilungen von Freunden der Naturwissenschaften in Wien; gesammelt und herausgegeben von Wilhelm Haidinger 7, 124-125.

Suess, E. 1854. Über die Brachiopoden der Kössener Schichten. Denkschriften der kaiserlichen Akademie der Wissenschaften 7, 29-65.

Suess, E. 1883-1909. Das Antlitz der Erde. Parts Ia, Ib, II, III/1, III/2. F. Tempsky, Wien and G. Freytag, Leipzig (For details and translations see Şengör, 2014).

Suess, E. 1916. Erinnerungen. 451 pp. Verlag von S. Hirzel, Leipzig.

TöRNQUIST, S.L. 1890. Undersökningar öfven Siljansomradets Graptoliter 1. Lunds Universitets Arsskrift, New Series 26, $1-33$.

Tullberg, S.A. 1883. Skånes Graptoliter 2. Graptolitfaunorna i Cardiolaskiffern och Cyrtograptusskiffrarne. Sveriges Geologiska Undersökning C55, 1-43.

Urbanek, A. 1958. Monograptidae from erratic boulders of Poland. Palaeontologia Polonica 9, 1-105.

Urbanek, A. 1997. Late Ludfordian and early Pridoli monograptids from the Polish lowland. Palaeontologia Polonica $56,87-231$. 
Urbanek, A. \& Teller, L. 1974. Sicula and thecae in Monograptus (Testograptus) testis. Special Papers in Palaeontology 13, 237-248.

Urbanek, A., Radzevičius, S., KozŁowska, A. \& Teller, L. 2012. Phyletic evolution and iterative speciation in the persistent Pristiograptus dubius lineage. Acta Palaeontologica Polonica 57(3), 589-611. DOI 10.4202/app.2010.0070

WALKER, M. 1953. The development of Monograptus dubius and Monograptus chimaera. Geological Magazine 90(5), 362-373. DOI 10.1017/S0016756800065638

YIN, T.H. 1937. Brief description of the Ordovician and Silurian fossils of Shihtien. Bulletin of the Geological Society of China 16, 281-302.

DOI 10.1111/j.1755-6724.1937.mp16001012.x

ZAPFe, H. 1981. Eduard Suess als Paläontologe. Mitteilungen der östereichischen geologischen Gesellschaft 74/75, 17-26.

Appendix. Identifications of the graptolite material illustrated by Eduard Suess (1851a). All species names are based on the latest taxonomic revision. The species are listed in order of illustration in Suess (1851a). Barrande (1852) discussed the taxa described by Suess (1851a) in some detail and provided interesting, but not always correct, information and interpretations. He identified many specimens with different names.

Suess, 1851a, pl. 7, fig. 1a, b. Retiolites geinitzianus Barrande, 1850. Malá Chuchle (Kuchelbad near Prague), Bohemia. F 443.

Suess, 1851a, pl. 7, fig. 1c, d. Retiolites geinitzianus Barrande, 1850. Hodkowiček (Prague-Hodkovičky), Bohemia, specimen not identified.

Suess, 1851a, pl. 7, fig. 1e. Retiolites geinitzianus Barrande, 1850. Hodkowiček, (Prague-Hodkovičky), Bohemia, specimen not identified.

Suess, 1851a, pl. 7, fig. 1f. Retiolites geinitzianus Barrande, 1850. Limestone, Wiskočilka (Vyskočilka) near Prague, (Malá Chuchle-Vyskočilka), Bohemia, specimen not identified.

Suess, 1851a, pl. 7, fig. 1g. Retiolites geinitzianus Barrande, 1850. Locality not known, specimen not identified.

Suess 1851a, pl. 7, fig. 2a, b. Stomatograptus grandis (Suess, 1851). Locality not known, specimen not identified.

Suess 1851a, pl. 8, fig. 1a. Parapetalolithus elongatus (Barrande, 1850). Petalolithus palmeus Suess, 1851 (in figure explanation). Locality not known. F 439b.

Suess 1851a, pl. 8, fig. 1b. ?Parapetalolithus palmeus (Barrande, 1850). The paper cited Suess as author of the species in the plate explanation. Specimen is not identified.

Suess 1851a, pl. 8, fig. 1c. Parapetalolithus palmeus (Barrande, 1850). Beroun area SW of Prague, Bohemia. F 440.

Suess 1851a, pl. 8, fig. 2. Parapetalolithus palmeus (Barrande, 1850). The specimen is the holotype of Petalolithus parallelocostatus Suess, 1851 (also listed as Petalolithus parallelo-costatus). Beroun area SW of Prague, Bohemia. F 460a.

Suess 1851a, pl. 8, fig. 3. ?Parapetalolithus palmeus (Barrande, 1850). The specimen was identified as Petalolithus ovatus Suess in the plate explanation and was not identified in the collection.
The paper cited Suess as author of the species in the plate explanation.

Suess 1851a, pl. 8, fig. 4. Parapetalolithus palmeus (Barrande, 1850). The specimen was identified as Petalolithus ovatus Suess in the plate explanation. Locality unknown. F 453a.

Suess 1851a, pl. 8, fig. 5. Monograptus priodon (Bronn, 1835). The specimen was originally identified as Graptolithus priodon Geinitz by Suess (1851a). The illustrated material appears to be based on pyritic casts of individual thecae. The material was not identified.

Suess 1851a, pl. 8, fig. 6. Bohemograptus bohemicus (Barrande, 1850). The material appears to be represented as ?pyritic thecae. The material was not identified.

Suess 1851a, pl. 8, fig. 7a, e. Testograptus testis (Barrande, 1850). The slab bears a poorly preserved specimen, difficult to see on the weathered shale surface as it is largely preserved as faint imprint with little remains of the organic fusellum. Litohlavy (formerly Litohlaw) near Beroun, Bohemia. F 445.

Suess 1851a, pl. 8, fig. 8a, f. Suess (1851a) identified the material as Graptolithus colonus Barrande, 1850, now Colonograptus colonus (Barrande, 1850). Malá Chuchle (Kuchelbad near Prague), Bohemia. The material may be identified as Monoclimacis sp. as was already suggested by Elles \& Wood (1902, p. 25) who regarded the material as "various aspects of Mon. vomerinus (Nicholson)'. The slab also contains the specimen of Retiolites geinitzianus, probably misidentified as the illustrated specimen in Suess (1851a, pl. 7, fig. 1). Barrande (1852, p. 150) questioned the identity of the material. NM L27509.

Suess 1851a, pl. 9, fig. 1a, e. Spirograptus turriculatus (Barrande, 1850). A large specimen was indicated to be in the National Museum, Prague (Suess, 1851a, p 122). It may be the specimen illustrated as Suess (1851a, pl. 9, fig. 1a). Information on the locality was not given, Litohlavy (formerly Litohlaw) 
near Beroun was listed as a locality at which the species is common. The material was not identified.

Suess 1851a, pl. 9, fig. 2. Torquigraptus proteus (Barrande, 1850). Holotype of Graptolithus armatus Suess, 1851. Malá Chuchle (Kuchelbad near Prague), Bohemia. NM L31095.

Suess 1851a, pl. 9, fig. 3a, d. Torquigraptus proteus (Barrande, 1850). Loydell (1993, p. 119) discussed the species in great detail. The material is not identified.

Suess 1851a, pl. 9, fig. 4. Stimulograptus becki (Barrande, 1850). Loydell (1993, p. 72) re-described the species. Přibyl (1948, p. 27) selected the specimen illustrated by Barrande (1850, pl. 3, fig. 15) from the Rastrites linnaei Biozone of Želkovice, Bohemia as the lectotype. The specimen has never been re-illustrated or re-described, but see Perner (1897) for the re-description and illustrations of the Barrande (1850) material. The specimen was not identified.

Suess 1851a, pl. 9, fig. 5a. Pristiograptus dubius (Suess, 1851). Malá Chuchle (Kuchelbad near Prague), Bohemia. Poorly preserved long fragment with nema visible distally. Specimen is indeterminable. NM L27505.

Suess 1851a, pl. 9, fig. 5b. Pristiograptus dubius (Suess, 1851). ?holotype, Prague-Dvorce, Bohemia. The specimen does not resemble the original illustration and may be misidentified. It is an unidentifiable fragment. NM L31094.

Suess 1851a, pl. 9, fig. 6a, b. Graptolithus laevis Hall, 1847. Malá Chuchle (Kuchelbad near Prague), Bohemia, specimen is flattened, does not show many details. NM L31093.

Suess 1851a, pl. 9, fig. 7a, b. Graptolithus ferrugineus Suess, 1851. The species is now identified as Expansograptus ferrugineus (Suess, 1851); see Bouček (1973), but a revision may be needed, as it has never been re-illustrated properly. Barrande (1852, p. 149) identified the specimens as poorly preserved examples of Graptolithus colonus. NM L7555.
Suess 1851a, pl. 9, fig. 8a, b. Monograptus sp., Malá Chuchle (Kuchelbad near Prague), Bohemia. Suess (1851a) illustrated only two small fragments as Graptolithus convolutus (now Lituigraptus convolutus), not showing the colony shape, but just providing an idea on the thecal style. Both illustrations may be taken from a single specimen. The specimen in the collection in Prague does not represent Lituigraptus convolutus (see Barrande, 1852, p. 151), but is a specimen of a Monograptus sp. of Monograptus priodon type, thus, must be misidentified. NM L31092.

Suess 1851a, pl. 9, fig. 9. Graptolithus taenius Sow. et Salter (text, p. 115); Graptolithus Taenia Sow. Salter (figure explanation). The specimen was not identified.

Suess 1851a, pl. 9, fig. 10a, b. Oktavites falx (Suess, 1851). Locality Malá Chuchle-Vyskočilka, Bohemia, Oktavites spiralis Biozone. NM L31091.

Suess $1851 \mathrm{a}$, pl. 9, fig. 11a, b. ?Stimulograptus sedgwickii (Portlock, 1843). Suess (1851a) identified the specimens as Graptolithus sedgwickii Harkness, while Barrande (1852, p. 151) questioned this identification. The recognized specimen could be the original to pl. 9 , fig. 11b. The deeply weathered slab contains a fragment of a large retiolitid. The specific identification of this poor fragment is uncertain. NM L31090.

Suess 1851a, pl. 9, fig. 12a, b. Streptograptus barrandei (Suess, 1851). Želkovice, Bohemia, Barrande collection. NM L31089.

Suess 1851a, pl. 9, fig. 13a, b. ?Demirastrites peregrinus (Barrande, 1850). Specimen not identified.

Suess 1851a, pl. 9, fig. 14a, b. Rastrites linnaei (Barrande, 1850). The specimen was not identified. Suess (1851a, p. 88) had access to specimens in the National Museum, Prague and the K.K. Geologische Reichsanstalt in Wien. According to Suess (1851a, pp. 87, 88) the illustrated specimen is from the Barrande collection. A specimen from the Bilimek collection is illustrated here (Fig. 4I). 